\section{Hydrobiological Issues in Ethiopia: In Case of Human and Natural Associated Issues on Fish Production}

\author{
Wudu Abiye ${ }^{1,2 *}$ \\ ${ }^{1}$ Hungarian University of Agriculture and Life science (MATE), Department \\ of Water Management and Climate change adaptation (MSc Student), 2100 \\ Godollo, Hungary)
}

${ }^{2}$ Amhara Agricultural Research Institute (ARARI), Sirinka Agricultural Research Center (SARC) (Assistant Soil and Water Management Researcher II), 74, Woldia, Ethiopi

\begin{abstract}
The goal of this review article was to look into Ethiopia's current fishery issues. Scientific articles, both published and unpublished, were employed as data sources. The impact of water hyacinth (mostly in Lake Tana and other Ethiopian rift valley lakes), expansion of agriculture and industrialization, climate change and post-harvest losses, improper fishing gears and poison plants, immature fishing and overfishing, wetland degradation, and fish diseases were among the current problems of Ethiopian fishes and fisheries, according to the review. The demand for fish has doubled in recent years. As a result, proper fisheries management is urgently needed, such as increasing capture fishing and aquaculture to preserve fish resources and meet demand for fish and fishery products.
\end{abstract}

Keywords: Ethiopia; Fish production; Lake

\section{Introduction}

Aquatic ecosystems are frequently regarded as highly productive biological systems that supply essential resources for human livelihood and management systems, such as drinking water, fishing, irrigation, power generation, transportation and recreation. Ethiopia is blessed with a diverse range of aquatic environments that are both scientifically and economically important [1].

Fish farming is performed in many countries around the world, including Ethiopia. In Ethiopia, fishery output is centered on ${ }^{\star}$ Corresponding author: Wudu Abiye, Hungarian University of Agriculture and Life Science, Godollo, Hungary; E-mail: wuduabiye@gmail.com

Citation: Abiye W (2021) Hydrobiological Issues in Ethiopia: In Case of Human and Natural Associated Issues on Fish Production. J Aquac Fisheries 5: 043.

Received: December 16, 2021; Accepted: December 28, 2021; Published: December 31, 2021

Copyright: ( 2021 Abiye W. This is an open-access article distributed under the terms of the Creative Commons Attribution License, which permits unrestricted use, distribution, and reproduction in any medium, provided the original author and source are credited.
Oreochromis niloticus, Clariasgariepinus, Cyprinus Carpio and Carassius Carasius, with Oreochromis niloticus, Clariasgariepinus, Cyprinus Carpio and Carassius Carasius being the most common species. With restricted access and production status in the food marketing system, its output is still underutilized [2]. The country boasts a diverse geological and climatic landscape, as well as abundant water resources and wetland habitats, including river basins, significant lakes, numerous swamps, floodplains and man-made reservoirs. The majority of the fish supply comes from the country's major lakes and reservoirs, such as Fincha, Hawassa, Tana, Chamo, Ziway, Koka, Abaya and rivers. The advantages derived from the development of fisheries are substantial. Fisheries have an essential role in food security, revenue generation, job development and nutrition security at all levels, from local to global [2].

Fisheries are an important and renewable natural resource basis for many developing countries and the fishing sector supports the livelihoods of many rural communities. As a result, fishing is an important sector for poverty reduction and might be viewed as a strategy because it helps to diversify household income both directly and indirectly [3].

Fish has always played a significant role in food security in many nations and continues to do so internationally, accounting for 15-20 percent of animal protein consumption. Fish farming is a practice that has been conducted in various places of the world, including Europe. Based purely on population size, Ethiopia now has an estimated annual total exploitable fish potential of 51,481 tons, which can only cover 79 percent of current real demand, 55 percent of projected need in 2010 and 44 percent of projected demand in 2015. Lake Tana, Ashenge, Hayk, Koka, Ziway, Langano, Awassa, Abaya and Chamo are just a few of Ethiopia's potentially fish-rich lakes [4] (Figure 1).

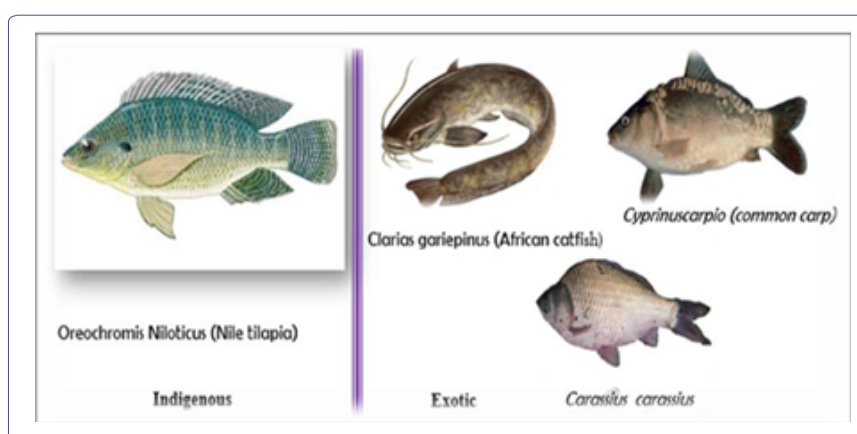

Figure 1: Most landing and preferred Fish Species in different water bodies.

\section{Challenges and Opportunities of Fish Production in Ethiopia}

\section{challenges of fish production}

Environmental degradation: Subsistence increases Agricultural expansion, deforestation, municipal and industrial effluents and human encroachment on the lake's shores have resulted in historically high 
nutrient loads [4]. Degradation and depletion have the greatest immediate impact on rural poverty; food insecurity, malnutrition and under nutrition are all closely linked to environmental degradation, since poverty depletes natural resources, exacerbating the misery of the rural poor. People are driven to farm marginal lands, reduce fallow seasons, chop important forests in their search for arable land or fuel, overstock delicate rangelands and overfish rivers, lakes, and coastal waters when their survival is at danger [5]. Mismanagement of resources, ineffective policies and institutions and insufficient technical and material backup to the sector and market are just a few examples. Furthermore, deforestation, coastline erosion, water pollution, siltation and eutrophication, as well as overfishing, are all threats to Ethiopian lakes, where inland fishing is primarily practiced [6] (Figure 2).

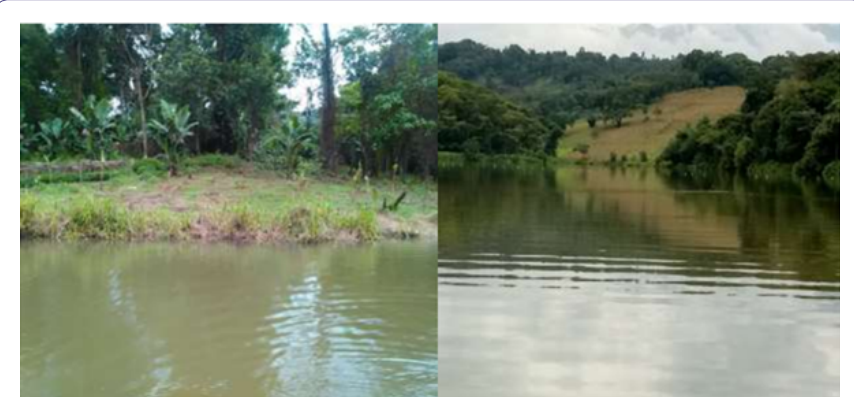

Figure 2: Agricultural activities and deforestation near Denbi reservoir [7].

Management of the fishery: The primary cause appears to be increased competition for open-access resources, whether it is damaging fishing around river mouths, inequitable resource use, or natural calamities such as storms when fish are on way to their spawning grounds upstream and over-reliance on one sort of asset and a lack of regard for the majority of fishermen's interests in lake alternatives Furthermore, a lack of government support, remote Ziway, the management of fisheries is primarily based on location and poor services, low literacy and innumeracy on closed seasons, closed fishing areas, restrictions on and weak organizational capacity are other factors that expose fishing communities to poverty. The number of beach seines limits and bans, as well as the number of beach seines fishermen and fishing gears, boosted the fishery resource [4].

Absence of adequate government support, poor policy and regulatory framework: The lack of proper government assistance for the growth of the fisheries sector is the second most serious issue raised by $98.26 \%$ of respondents. Similarly, according to the poll, weak policy and regulatory framework (65.12 percent) is one of the key issues facing fishing households. The presence of a fishery proclamation, which aids in the control of illicit fishing instruments, the protection of fisheries from overfishing, and the maintenance of the overall fishing environment, did not protect the sector. Approximately 59.30 $\%$ of the farmers also stated that they were experiencing difficulties due to a lack of basic infrastructure and fishing equipment [5].

Climatic changes and fish disease: Ethiopia is suffering from a severe drought and food insecurity problem as a result of a lack of rains and droughts, which have been exacerbated by El Nino in 2015 . Climate change is causing major depletion of fisheries in a certain country. By affecting water quality and the trophic status of a specific aquatic habitat, higher inland water temperatures reduce the availability of fish species. Climate change may also make fishing households more vulnerable. Because agricultural crops have been severely harmed as a result of climate change, the only alternative is to catch any size of fish and the fish population in Lake Lange no has become overexploited.

Due to rainfall variations, the highest runoff sometimes occurred in different places, resulting in silt load in the water bodies. Sediment load and siltation are current issues in Lake Tana.

Similarly, variations in fish species diversity, size and composition have been reported in Lake Zeway as a result of climate variability and change on fishery resources. Chemical pollution from runoff from irrigated farms and siltation of the lake due to soil erosion due to deforestation have also been documented in the vicinity.

Diseases have also harmed the country's seafood output. Fish illnesses are one of the difficulties facing the country's fishing sector, according to Meko et al. Fish production potential is lowered due to parasites and disease-related circumstances. It is the world's most common and serious problem in both catch fishing and aquaculture. It could result in a high rate of mortality in a specific water body or fishing spot.

Expansion of water hyacinth: In terms of harmful consequences on aquatic ecosystems, agriculture, fisheries, transportation, living conditions, and social structures, water hyacinth (Eichhorni acrassipses) has been deemed the worst invasive weed. The usage and reduction of dissolved oxygen by water hyacinths resulted in fish fatalities due to oxygen depletion. This plant is now the primary cause of diminishing fish output in a variety of lakes. According to Wassie et al, according to reports, the water hyacinth infestation in Lake Tana has spread over 34,500 hectares (15 percent of the Northern shore). As a result of the water hyacinth expansion obstructing their fishing activity, all of the fishermen moved their landing sites. "If the expansion of water hyacinth continues in this trend, it can significantly influence the livelihood of fishers in both directions by increasing fishing costs and diminishing the amount of fish caught in Lake Tana," the paper concluded.

Water pollution: Koka Lake and its aquatic habitat have been under increasing anthropogenic strain due to its closeness to the capital city and neighboring industrial cities. Other big stumbling blocks include pollution from various enterprises and the proximity of large irrigation farms. This issue was mentioned by 78.5 percent of those polled. Chemicals that damage the Lake's water quality as well as its environment, according to the respondents, are primarily emitted from several factories in the district, particularly around Mojo Town and through the Mojo River. According to the fishing households' responses from Dhungugi Bekele Kebele, chemical pollutants generated by Ethiopia Tannery PLC have an impact on lake biodiversity, particularly the fish resource. They noticed pollution as a result of it [5] (Figure 3).

Lack of improved technologies and thefts: Fishing households replied positively to the existence of a lack of updated technology and theft issues, with 55.81 percent and 28.49 percent, respectively. The lake is primarily exploited by illicit fishing materials, according to all focus group discussants from fishing households, due to weak lake management and control mechanisms. This resulted in an increase in illegal fishing and theft issues at several landing sites. During the offfarm and fasting seasons, the situation is most acute [5].

Lack of basic infrastructure and fishing equipment's: 59.30 Percent of respondents cited a lack of basic infrastructure and fishing equipment as major issues, while 67.44 percent of respondent fishing 

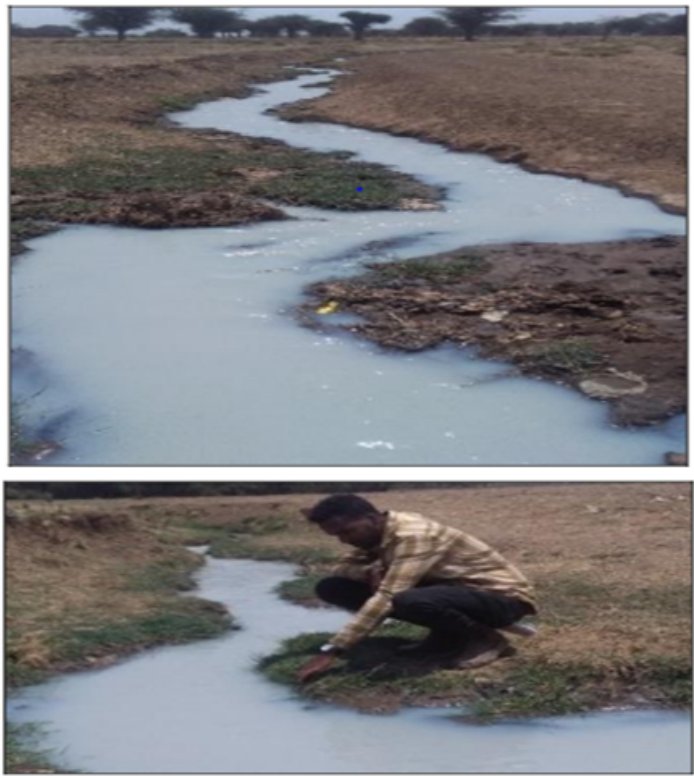

Figure 3: Waste disposal canal to Lake Koka from Ethiopian tannery, February, $15 / 2020$.

households cited an insufficient value chain and a lack of a solid market as barriers to their fishing activity. According to my observations, fishermen lacked a stable location and storage facility in which to store harvested fish until they could be sold. Fishermen were preparing fish fillet at the lake shore, a site that was not clean enough and could cause hygiene issues, according to personal observation. As a result of a lack of storage and transportation [5].

Overfishing: Because the fisheries in Ethiopia is accessible to everybody, there has been localized overfishing, putting some commercially significant species and overall resources at risk. In most cases, fish are caught before they reach sexual maturity in various aquatic bodies. According to a report by, substantial proportions of Labeobarbus intermedius collected in the Koka reservoir were under length at first maturity. Similarly, immature fishing was seen in Lake Hawassa $(77.6 \%)$ for Clariasgariepinus and $(23.0 \%)$ for Oreochromis niloticus and in Lake Tana (15\%) for Labeobarbus species.

Urbanization, agricultural expansion and wetland degradation: Expansion of agriculture, industrial pollution, drainage activities and destruction of wetland trees for home consumption and money generation are the most significant risks to the coastline wetlands stability, according to Wondie. The real production in Lake Ziway dropped from 2300 tons/year in 2003 to 1127 tons/year in 2011 due to the destruction of fish breeding grounds. According to the FAO, sewage from manufacturing and agriculture are the main sources of pollution harming Ethiopian water bodies and fish, posing a serious threat to fisheries.The extraction of minerals from Lake Abijata, like the effluents from the tannery at Koka Reservoir and the textile industry at Awassa and Arba Minch, could have a deleterious impact on fish supplies (Table 1).

\section{opportunities of fish production}

Availability of commercially consumed fish species: Three economically important fish species that are employed as a source of income in the market, according to [5]. The main targeted and leading

\begin{tabular}{|c|c|c|c|}
\hline Challenges & $\begin{array}{c}\text { Frequen- } \\
\text { cy }\end{array}$ & Percent & Rank \\
\hline Water hyacinth & 172 & 100 & 1 \\
\hline $\begin{array}{c}\text { Lack of basic infrastructure and fishing } \\
\text { equipment's }\end{array}$ & 102 & 59.3 & 6 \\
\hline Lack of improved technology & 96 & 55.81 & 7 \\
\hline insufficient value chain and reliable market & 116 & 67.44 & 4 \\
\hline $\begin{array}{c}\text { Poor policy and regulatory frame work for } \\
\text { fishing }\end{array}$ & 112 & 65.12 & 5 \\
\hline Inadequate government support & 169 & 98.26 & 2 \\
\hline Water pollution & 135 & 78.5 & 3 \\
\hline Theft & 49 & 28.49 & 8 \\
\hline
\end{tabular}

Table 1: The major challenges in fishing activities.

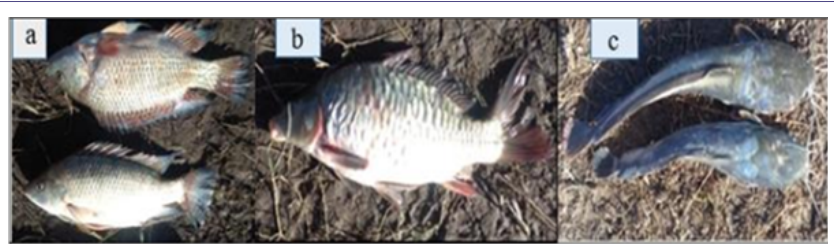

Figure 4: Targeted fish species at Lake Koka.

species in overall production were Nile tilapia (Oreochromis niloticus), Common carp (Cyprinus carpio) and Catfish (Clariasgariepinus) (Figure 4). Consumer demand for such fish species was higher at all levels of the fish market.

Good market outlet: Lume district was discovered at the heart of numerous large cities and towns around the country, according to [5]. In comparison, the district enjoys good road and seafood marketing connections. According to this research, approximately 97.09 percent of respondents stated that the Lume district offers an excellent market outlet for boosting fish marketing Koka". However, she stated that, due to the lack of a well-established fish value chain, farmers are not benefiting as much as they should from this major opportunity.

Free access to water bodies: Lume district, according to [5], Koka Lake is bordered by Bora, Adama and Dodota districts. For those districts, the presence of such a lake serves and supports various households in a variety of ways, from fishing to animal watering and home consumption. The existence of Lake Koka was mentioned by 95.35 percent of fishing households as a positive potential for the growth of the fisheries.

Small initial capital: According to [5], when compared to other farm activities, 70.93 percent of fishing households specify that fishing requires a low initial capital investment for newcomers. They also acknowledged that if fishing activities are carried out in a sustainable manner, it will provide a chance to help rural populations' livelihoods, particularly for those living near water bodies (Table 2).

\begin{tabular}{|c|c|c|c|}
\hline Opportunities & Frequency & Percent & Rank \\
\hline Small initial capital & 122 & 70.93 & 5 \\
\hline Free access to water bodies & 164 & 95.35 & 4 \\
\hline $\begin{array}{c}\text { Increase demand } \\
\text { Availability of commercially consumed } \\
\text { fish species }\end{array}$ & 172 & 100 & 1 \\
\hline Good market out let & 167 & 99.42 & 2 \\
\hline
\end{tabular}

Table 2: Opportunities for Fishing [5]. 


\section{Summary and Conclusion}

In Ethiopia, there are different rivers, lakes, and reservoirs in various parts of the nation that have the potential to be used for fish farming and development. Although a significant number of individual fisherman operate outside the framework of cooperatives, simply because it is open access resources, most fishermen in Ethiopia are organized in cooperatives, representing the communities around the lake, reservoirs and the islands.

In Ethiopia, fish handling is at its lowest point and is still in its traditional stage. Fish are processed/filleted on the floors of boats after being caught with a net or hook and are usually sold along the shorelines of water bodies. According to the data analyzed, the country's fishing production system is primarily artisanal in character, employing traditional techniques and instruments. Despite the fact that fish contributes significantly to the fishing industry, it is characterized by low production and underutilization due to rudimentary and labor-intensive fishing gears, inaccessibility to potential market areas, lack of developed processing technology, lack of government support, lack of strong and well-functioning policy, overfishing, illegal fishermen, shore cultivation, deforestation and lack of train.

\section{Recommendation}

According to the literature, fishermen continue to employ archaic boats with weak handling and transporting systems in all fish prospective locations. As a result, both the federal and regional governments should prioritize supplying appropriate basic fishing equipment and establishing fundamental infrastructure such as roads, transit systems, energy, and storage facilities. In addition, effective management methods, effective training, extension work, and ongoing assistance should be done, all of which include active participation of the fishing community.

Overfishing and the growth of unlawful fishermen are the result of commercial gillnet fishing's poorly regulated high fishing effort. To keep the stock of the resource viable, management methods such as closed seasons, catch quota restrictions, mesh size requirements, gear restrictions, limits on the number of fishers and/or boats, effort taxes, and activity licensing must be implemented. As a result, the government should monitor each fishing activity in many areas relating to resource consumption and management on a regular basis.

Anthropogenic activities, increasing pollution from waste disposal, cultivating the lakeshore, climate change, and the recently developed weed (water hyacinth) pose a significant danger to various water bodies and the fishing sector in particular, are all limiting fish output. As a result, the government and other interested parties must collaborate to develop measures for minimizing anthropogenic activities and water hyacinth, as well as control mechanisms.

Finally, the present severe difficulty water hyacinth is rapidly expanding on the main water bodies and most fishermen are not cooperating and failing to develop strong cooperation in order to manage and exploit the resource in a sustainable manner. Furthermore, the industries rely on a conventional system in the absence of modern and well-coordinated value chain-based fish production, processing, and marketing. This all mentioned problems are some of the research gap that needs a critical and proper assessment in all fish potential area to sustain the sector with its grate contribution for the whole economic activities of the country. So, any interested search organization or individual researcher should be conducting the research on indicated direction. All of the aforementioned issues are examples of research gaps that require a thorough examination of all fish potential areas in order to sustain the sector and its valuable contribution to the country's overall economic activity. As a result, any interested search organization or individual researcher should do research in the above-mentioned direction.

\section{References}

1. Abhachire LW (2014) Studies on hydrobiological features of Koka Reservoir and Awash River in Ethiopia. International Journal of Fisheries and Aquatic Studies 1: 158-162.

2. Hebano AH, Zone S, Wake EAA, Wake AA (2020) Overview of Ethiopian fisheries production system and its challenges in different fish potential area: A review. International Journal of Fisheries and Aquatic Studies 8: 148-156.

3. Olale E, Henson S (2013) The impact of income diversification among fishing communities in Western Kenya. Food Policy 43: 90-99.

4. Tilahun A (2016) Fish production constraints in Ethiopia: A Review. World Journal of Fish and Marine Sciences 8: 158-163.

5. Wake AA (2021) Opportunities and its challenges in fish production: The case of Lake Koka, East Showa Zone, Oromia National Regional State, Ethiopia. International Journal of Fisheries and Aquatic Studies, 9: 1-5.

6. Demeke M, Guta F, Ferede T (2004) Agricultural development in Ethiopia: Are there alternatives to food aid? Agricultural Development.

7. Askale G, Tegegn F (2019) Assessment of the fishery, challenges and opportunities of Denbi reservoir in Bench Maji Zone, South Western part of Ethiopia. International Journal of Fisheries and Aquaculture 11: 7-12. 


\section{H}

Advances In Industrial Biotechnology | ISSN: 2639-5665

Advances In Microbiology Research | ISSN: 2689-694X

Archives Of Surgery And Surgical Education | ISSN: 2689-3126

Archives Of Urology

Archives Of Zoological Studies | ISSN: 2640-7779

Current Trends Medical And Biological Engineering

International Journal Of Case Reports And Therapeutic Studies | ISSN: 2689-310X

Journal Of Addiction \& Addictive Disorders | ISSN: 2578-7276

Journal Of Agronomy \& Agricultural Science | ISSN: 2689-8292

Journal Of AIDS Clinical Research \& STDs | ISSN: 2572-7370

Journal Of Alcoholism Drug Abuse \& Substance Dependence | ISSN: 2572-9594

Journal Of Allergy Disorders \& Therapy | ISSN: 2470-749X

Journal Of Alternative Complementary \& Integrative Medicine | ISSN: 2470-7562

Journal Of Alzheimers \& Neurodegenerative Diseases | ISSN: 2572-9608

Journal Of Anesthesia \& Clinical Care | ISSN: 2378-8879

Journal Of Angiology \& Vascular Surgery | ISSN: 2572-7397

Journal Of Animal Research \& Veterinary Science | ISSN: 2639-375

Journal Of Aquaculture \& Fisheries | ISSN: 2576-5523

Journal Of Atmospheric \& Earth Sciences | ISSN: 2689-8780

Journal Of Biotech Research \& Biochemistry

Journal Of Brain \& Neuroscience Research

Journal Of Cancer Biology \& Treatment | ISSN: 2470-7546

Journal Of Cardiology Study \& Research | ISSN: 2640-768X

Journal Of Cell Biology \& Cell Metabolism | ISSN: 2381-1943

Journal Of Clinical Dermatology \& Therapy | ISSN: 2378-8771

Journal Of Clinical Immunology \& Immunotherapy | ISSN: 2378-8844

Journal Of Clinical Studies \& Medical Case Reports | ISSN: 2378-880

Journal Of Community Medicine \& Public Health Care | ISSN: 2381-1978

Journal Of Cytology \& Tissue Biology | ISSN: 2378-9107

Journal Of Dairy Research \& Technology | ISSN: 2688-9315

Journal Of Dentistry Oral Health \& Cosmesis | ISSN: 2473-6783

Journal Of Diabetes \& Metabolic Disorders | ISSN: 2381-201X

Journal Of Emergency Medicine Trauma \& Surgical Care | ISSN: 2378-8798

Journal Of Environmental Science Current Research | ISSN: 2643-5020

Journal Of Food Science \& Nutrition | ISSN: 2470-1076

Journal Of Forensic Legal \& Investigative Sciences | ISSN: 2473-733X

Journal Of Gastroenterology \& Hepatology Research | ISSN: 2574-2566
Journal Of Genetics \& Genomic Sciences | ISSN: 2574-2485

Journal Of Gerontology \& Geriatric Medicine | ISSN: 2381-8662

Journal Of Hematology Blood Transfusion \& Disorders | ISSN: 2572-2999

Journal Of Hospice \& Palliative Medical Care

Journal Of Human Endocrinology | ISSN: 2572-9640

Journal Of Infectious \& Non Infectious Diseases | ISSN: 2381-8654

Journal Of Internal Medicine \& Primary Healthcare | ISSN: 2574-2493

Journal Of Light \& Laser Current Trends

Journal Of Medicine Study \& Research | ISSN: 2639-5657

Journal Of Modern Chemical Sciences

Journal Of Nanotechnology Nanomedicine \& Nanobiotechnology | ISSN: 2381-2044

Journal Of Neonatology \& Clinical Pediatrics | ISSN: 2378-878X

Journal Of Nephrology \& Renal Therapy | ISSN: 2473-7313

Journal Of Non Invasive Vascular Investigation | ISSN: 2572-7400

Journal Of Nuclear Medicine Radiology \& Radiation Therapy | ISSN: 2572-7419

Journal Of Obesity \& Weight Loss | ISSN: 2473-7372

Journal Of Ophthalmology \& Clinical Research | ISSN: 2378-8887

Journal Of Orthopedic Research \& Physiotherapy | ISSN: 2381-2052

Journal Of Otolaryngology Head \& Neck Surgery | ISSN: 2573-010X

Journal Of Pathology Clinical \& Medical Research

Journal Of Pharmacology Pharmaceutics \& Pharmacovigilance | ISSN: 2639-5649

Journal Of Physical Medicine Rehabilitation \& Disabilities | ISSN: 2381-8670

Journal Of Plant Science Current Research | ISSN: 2639-3743

Journal Of Practical \& Professional Nursing | ISSN: 2639-568

Journal Of Protein Research \& Bioinformatics

Journal Of Psychiatry Depression \& Anxiety | ISSN: 2573-0150

Journal Of Pulmonary Medicine \& Respiratory Research | ISSN: 2573-0177

Journal Of Reproductive Medicine Gynaecology \& Obstetrics | ISSN: 2574-2574

Journal Of Stem Cells Research Development \& Therapy | ISSN: 2381-2060

Journal Of Surgery Current Trends \& Innovations | ISSN: 2578-7284

Journal Of Toxicology Current Research | ISSN: 2639-3735

Journal Of Translational Science And Research

Journal Of Vaccines Research \& Vaccination | ISSN: 2573-0193

Journal Of Virology \& Antivirals

Sports Medicine And Injury Care Journal | ISSN: 2689-8829

Trends In Anatomy \& Physiology | ISSN: 2640-7752

Submit Your Manuscript: https://www.heraldopenaccess.us/submit-manuscript 